\title{
Część IV
}

\section{Niektóre aspekty rozwoju współczesnej rachunkowości}

Katarzyna Olak, Chrystian Musiat*

\section{Systemy nadzoru korporacyjnego w Polsce i w Niemczech - analiza porównawcza}

\section{Wprowadzenie}

Nadzór korporacyjny to coraz bardziej znaczące pojęcie w dziedzinie zarządzania. Nadzór korporacyjny zajmuje się utrzymywaniem równowagi pomiędzy interesami a osobami związanymi z firmą. Regularna kontrola i ocena działalności ma zapewnić odpowiedni poziom zarządzania, który ma doprowadzić do wzrostu wartości i konkurencyjności firmy.

Celem rozdziału jest porównanie specyfiki nadzoru korporacyjnego w Polsce i w Niemczech. Pokazuje on, w jaki sposób firmy w tych dwóch krajach dostosowują się do obecnych reguł prawnych dotyczących nadzoru korporacyjnego oraz jakie rozwiązania stosują, aby zapewnić jak największą przejrzystość działalności. Do badania wykorzystaliśmy sprawozdania skonsolidowane obu firm za rok 2015. Skupiamy się na analizie informacji dotyczących systemu nadzoru korporacyjnego w firmie.

\footnotetext{
* Studenci ze Studenckiego Koła Naukowego Rachunkowości SIGMA, Uniwersytet Łódzki, Wydział Zarządzania, Katedra Rachunkowości, ul. Matejki 22/26, 90-237 Łódź.
} 


\section{System nadzoru korporacyjnego}

\subsection{Definicja nadzoru korporacyjnego}

Nadzór korporacyjny to pojęcie wywodzące się z angielskiego terminu: corporate governance thumaczone jako „nadzór korporacyjny”, „ład korporacyjny". Istnieje wiele definicji nadzoru korporacyjnego zależnie od zróżnicowania gospodarczego i kulturowego. W definicjach pojawiają się określenia:

$\checkmark$ system oceny działalności organów zarządzania,

$\checkmark$ sposób rozliczania menadżerów przed grupami udziałowymi,

$\checkmark$ system kierowania i kontroli korporacji,

$\checkmark$ mechanizmy ułatwiające zarządzanie i kontrole spółki.

Analizując powyższe określenia można uogólnić definicje. Nadzór korporacyjny oznacza system nadzoru nad działalnością spółek kapitałowych i spółek akcyjnych, sprawowany przez właścicieli, jak i osoby bezpośrednio i pośrednio zainteresowane działalnością spółki. Jest to system rozpatrywany na płaszczyźnie formalnej i nieformalnej ${ }^{1}$.

$\mathrm{Na}$ płaszczyźnie formalnej nadzór korporacyjny jest egzekwowany przez państwo i jego organy oraz kształtowany jest przez regulacje prawne $^{2}$ :

$\checkmark$ prawo działalności gospodarczej - odnosi się do zakresu odpowiedzialności właścicieli oraz sposobu i zakresu kontroli nad działalnością,

$\checkmark$ zasady dobrych praktyk (zebrane kodeksy) - zbierają rozwiązania, dzięki którym korzyści wszystkich interesariuszy mogą być maksymalizowane, $\checkmark$ regulaminy giełdy papierów wartościowych - nadzór korporacyjny dotyczy głównie publicznych spółek giełdowych, dlatego przestrzeganie tych regulaminów ma duże znaczenie. Zawierają one zasady mające na celu zwiększenie przejrzystości działalności korporacji, co usprawnia ich nadzór,

$\checkmark$ wewnętrzne dokumenty przedsiębiorstwa, takie jak statut oraz wewnętrzne akty prawne regulują działalność organów wewnętrznych przedsiębiorstwa,

\footnotetext{
${ }^{1}$ J. Penc, Encyklopedia zarządzania. Podstawowe kategorie i terminy, Wyższa Szkoła Studiów Międzynarodowych, Łódź 2008, s. 524.

${ }^{2}$ K. Lis, Nadzór korporacyjny, Oficyna Ekonomiczna, Kraków 2005, s. 7-9.
} 
$\checkmark$ inne akty prawne, takie jak: prawo cywilne, Ustawy o rachunkowości, kodeksy etyczne.

Płaszczyzna nieformalna to wszelkie czynniki kulturowe i tradycja, które wpływają na samo postrzeganie pojęcia nadzoru korporacyjnego, jak również na praktykowanie go. Zależnie od kultury kształtowany jest model nadzoru oraz istota i rola korporacji w gospodarce.

Celem nadzoru korporacyjnego jest dążenie do wyrównania znaczenia menadżerów, właścicieli i wszystkich grup zainteresowanych działalnością korporacji, aby każdy z zainteresowanych w równym stopniu miał zaspokojone wymagania wobec firmy. Istnieje on po to, żeby zapobiec niewłaściwym praktykom menadżerów m.in.: przywłaszczeniu majątków, niewłaściwemu gospodarowaniu środkami przedsiębiorstw, dążeniu do rozwoju firmy z własnych ambicji, a nie z potrzeby maksymalizacji majątku właściciela. Nadzór korporacyjny uzgadnia cel organizacji i nadaje jej kierunek strategiczny, a następnie zapewnia jawność i przejrzystość jej działalności oraz monitoruje jej działanie.

\subsection{Historia nadzoru korporacyjnego}

Temat nadzoru korporacyjnego pojawił się już w starożytności - Został on przedstawiony w „Odysei” Homera jako problem rozdzielania własności i zarządzania nią. Wprowadzenie pojęcia nadzoru korporacyjnego do ekonomii miało miejsce w 1776 roku wraz z wydaniem książki. A. Smitha „The Wealth of Nations”. Autor zwrócił w niej uwagę głównie na aspekt rozdzielenia własności i kontroli w korporacjach i do jakich konsekwencji to rozdzielenie prowadzi. Nie istniało jednak wtedy zainteresowanie problemem - powrócono do niego dopiero w latach trzydziestych XX wieku. Wówczas zostało wprowadzone pojęcie corporate governance (nadzór korporacyjny), które funkcjonuje do dziś. Nastąpiło to w 1932 roku wraz z wydaniem pracy „The Modern Corporation and Private Property” przez A. Berle'a i G. Meansa. Ostatecznie nadzór korporacyjny zaczęto doceniać od początku XIX wieku, kiedy zaczynały istnieć większe firmy wzrosło zapotrzebowanie na kapitał. 


\subsection{Modele i mechanizmy nadzoru korporacyjnego}

Ze względu na różnorodność postrzegania nadzoru korporacyjnego pod względem różnych kultur i tradycji powstało kilka modeli teoretycznych rozumienia tego pojęcia. Mają one na celu uogólnienie różnych podejść do nadzoru i dzięki którym łatwiej zrozumieć systemy występujące w różnych krajach. Wyróżnia się następujące modele postrzegania nadzoru’:

$\checkmark$ model finansowy - jest on określeniem systemu w krajach, w których najważniejszą wartością jest zysk; model ten występuje, gdy właściciele kapitału mają mały wpływ na podejmowanie decyzji w sprawie inwestycji i ma za zadanie zaprojektowanie procesów działalności tak, aby zwiększyć komunikację między właścicielami a menedżerami, dzięki czemu ułatwiona będzie kontrola i zaistnieje możliwość sprostania oczekiwaniom właścicieli;

$\checkmark$ model odpowiedzialnego gospodarza - występuje w krajach, w których istnieje nacisk na odpowiedzialność i samorealizację; w tym modelu menadżerowie osiągają swoje korzyści poprzez świadomość spełnienia obowiązku i osiągniecie zysku dla właścicieli; motywy obydwu grup zainteresowanych są zbieżne, dlatego w tym modelu nadzór mógłby mieć działanie demotywujące; nadzór korporacyjny w tym modelu jest ograniczony do funkcji doradczej;

$\checkmark$ model polityczny - występuje w krajach, w których prawo daje większe uprzywilejowanie właściciela korporacji, jednocześnie dając wolność menedżera w procesie decyzyjnym; tym modelu pomijane są inne grupy interesariuszy, a rola nadzoru korporacyjnego jest uwzględnienie wszystkich grup interesariuszy;

$\checkmark$ model interesariusza - występuje w krajach, w których państwo nie ma wpływu na podział korzyści pomiędzy grupami zainteresowania w organizacji; podziały te występują naturalnie, a zadaniem nadzoru korporacyjnego w tym przypadku jest zachowanie sprawiedliwego podziału; sprawowanie nadzoru dotyczy wszystkich grup interesariuszy.

\footnotetext{
${ }^{3}$ K. Lis, Nadzór korporacyjny, Oficyna Ekonomiczna, Kraków 2005, s. 3-4.
} 


\section{System nadzoru korporacyjnego na przykładzie Polski oraz Niemiec}

\subsection{Rodzaje modeli nadzoru korporacyjnego}

Systemy nadzoru korporacyjnego dzielą się na dwa podstawowe modele. Model anglosaski obowiązuje w Stanach Zjednoczonych oraz w Wielkiej Brytanii. Oparty jest on na podejściu rynkowym. Akcje w tych krajach znajdują się w rękach wielu akcjonariuszy i to kapitał własny stanowi większą część pasywów. Banki inwestycyjne nie mają dużego wpływu na operacje spółki. W tych krajach dużo większe znaczenie ma przejrzysta księgowość, ponieważ to w oparciu o nią akcjonariusze decydują o tym, jakie korzyści może zapewnić im spółka. Spółki koncentrują się na osiąganiu wysokich wyników oraz ochronie akcjonariuszy, a wartość przedsiębiorstwa w długim okresie jest odsunięta na drugi plan. Mechanizm rynkowy aktywnie kontroluje korporacje, weryfikując modele biznesowe. Skuteczne systemy wzmacniają swoją pozycję na rynku, a nieskuteczne zostają z niego wyeliminowane. Ze względu na niewielką ingerencję dużych podmiotów w wewnętrzne sprawy spółek, działania zarządu są bardzo istotne. W tym celu zarząd otrzymuje duże wynagrodzenie, zależne od wyników spółki. Nadzór korporacyjny jest sprowadzony do jednego organu.

Model kontynentalny obowiązuje w Europie kontynentalnej oraz w Japonii. W niektórych klasyfikacjach model kontynentalny jest dodatkowo podzielony na modele germański, łaciński oraz japoński. Podejście to jest oparte na relacjach inwestorskich. Charakteryzuje się on koncentracją akcji i większym zaangażowaniem banków w operacje spółki. Na skutek tego, rynek kontroli korporacji nie jest aż tak istotny jak w przypadku modelu anglosaskiego. Przedsiębiorstwa są nastawione na długookresowy rozwój i zwiększanie wartości akcji firmy, a nie na regularne wypłaty w postaci dywidend. Wynika to ze struktury finansowania i priorytetów finansujących podmiotów - banki są zainteresowane wzrostem cen akcji bardziej niż regularnymi wypłatami dywidendy. Sukces przedsiębiorstwa jest mierzony satysfakcją interesariuszy, a nie stopniem realizacji zamierzeń akcjonariuszy. Przedsiębiorstwa działające w tym modelu są zorientowane na stabilność i bezpieczeństwo, a nie na intensywny rozwój firmy. Zachowawczość tego modelu ogranicza konkurencyjność oraz może doprowadzić do 
sztucznego utrzymywania przynoszącego stratę przedsiębiorstwa. Zaangażowanie dużych podmiotów finansowych, grup oligarchicznych oraz państwa zaburza weryfikację stanu przedsiębiorstwa przez rynek. Struktura nadzoru korporacyjnego dodatkowo wzmacnia obecnie istniejący status quo.

Pomimo różnic $\mathrm{w}$ tych modelach, systemy nadzoru korporacyjnego pełnią podobną funkcję oraz korzystają z identycznych narzędzi. W dalszej części rozdziału omówione zostaną podobieństwa oraz różnice pomiędzy systemami obowiązującymi w dwóch różnych krajach modelu kontynentalnego - Polski i Niemiec.

\subsection{System nadzoru korporacyjnego w Polsce}

Najważniejsze informacje dotyczące nadzoru korporacyjnego w Polsce są zawarte w Kodeksie Spółek Handlowych, uchwalonym w 2001 roku. Określa on podstawowe zasady dotyczące struktury korporacji (podział na zarząd oraz radę nadzorczą), sposoby dotyczące rozwiązywania wewnętrznych problemów, możliwości wpływu akcjonariuszy liczne prawa dotyczące ochrony niewielkich grup akcjonariuszy (jest to szczególnie istotne, ze względu na omówioną wcześniej wraz z modelem kontynentalnym, dużą koncentrację akcji). Kwestia ta jest zwykle rozwiązywana poprzez wprowadzenie do rady nadzorczej osób, które reprezentują interesy pozostałych grup interesariuszy (np. pracowników lub udziałowców mniejszościowych). Kodeks Spółek Handlowych jest bieżąco aktualizowany tak, aby umożliwić skuteczne podążanie za zmianami w obecnej sytuacji gospodarczej. Akcjonariusze mają prawa głosowania za pomocą poczty elektronicznej lub internetu, rozpowszechniania informacji przez strony internetowe korporacji, a w komisjach audytowych musi uczestniczyć przynajmniej jeden niezależny profesjonalista. System ten najbardziej przypomina model germański, z wysokim wskaźnikiem koncentracji akcji oraz koncentracją na długofalowych efektach ${ }^{4}$.

Pomimo dobrze zorganizowanej struktury prawnej, w Polsce wciąż istnieją problemy dotyczące wprowadzania $\mathrm{w}$ życie tych ambitnych założeń. W początkowej fazie przemian ustrojowych, korporacje były finanso-

${ }^{4}$ Ch. Mallin, Handbook on International Corporate Governance, wyd. 2, Cheltenham, Edward Elgar Publishing, Nowy Jork 2011, s. 177-191. 
wane przez stosunkowo zróżnicowany kapitał. Obecnie jednak następuje coraz większa koncentracja kapitału. Wewnętrzne układy oraz nierespektowanie prawa tworzą okazje do nadużyć. W początkowej fazie przemian zwykle nadużycia te wychodziły ze strony środowisk menedżerskich na różnych szczeblach. Niedoskonały system nadzoru korporacyjnego umożliwiał menedżerom wykorzystywanie okazji do pozyskiwania dodatkowych zysków z racji swojej pozycji. Najczęściej objawiało się to w postaci bardzo wysokich wynagrodzeń, licznych uprzywilejowanych akcji oraz nieudostępniania istotnych informacji akcjonariuszom.

Obecnie natura nadużyć uległa zmianie. W ostatnich latach można zauważyć liczne naruszenia praw akcjonariuszy. Wysoki wskaźnik koncentracji kapitału umożliwia głównym akcjonariuszom nadużywanie swojej pozycji względem mniejszych akcjonariuszy. Częstą praktyką jest stosowanie transferu zysków. Polega to na sprzedawaniu spółce-matce towarów po zaniżonej cenie lub z dodatkowymi opłatami, a następnie odsprzedaniu ich spółce - córce po zawyżonej cenie. Istnieje podejrzenie, że praktykę te stosował Michelin, przenosząc zyski zależnej spółki Stomil Olsztyn.

Innym przykładem zwiększania swojej władzy przez głównych akcjonariuszy jest sprzedawanie akcji uprzywilejowanych po zaniżonych cenach. Główni akcjonariusze skupują je, zanim mniejsi właściciele są w stanie wziąć udział w przetargu, zwiększając swoją kontrolę nad przedsiębiorstwem kosztem mniejszych akcjonariuszy. Nieścisłości prawne pozwalały także na przejmowanie spółek z pominięciem obowiązkowej licytacji.

Pomimo licznych wad, błędów oraz nadużyć, które zanotowano w ciągu ostatnich kilkunastu lat, polska kultura nadzoru korporacyjnego rozwija się $\mathrm{w}$ dobrym kierunku. Istotna poprawa sytuacji w porównaniu do początku okresu przemian dobrze świadczy o działaniach ustawodawcy w tym zakresie. Istotna część tych udoskonaleń jest skutkiem działań Unii Europejskiej oraz rosnącego zainteresowania skutecznością infrastruktury prawnej. Największe problemy sprawia wprowadzenie poprawnych założeń prawnych w życie oraz skuteczne zwalczanie nadużyć. Skutecznym rozwiązaniem tego problemu może być zwiększenie aktywizmu akcjonariuszy, poprawienie prywatnych oraz publicznych akcji mających na celu implementację i przestrzeganie norm prawnych przez korporacje oraz kampanie poprawiające publiczną świadomość dotyczącą tego tematu. 
Podsumowując, kluczowe zalety obecnego systemu nadzoru korporacyjnego w Polsce to m.in. ${ }^{5}$ :

$\checkmark$ pojawienie się zainteresowania tematem nadzoru korporacyjnego w świadomości publicznej;

$\checkmark$ polepszenie standardów prawnych dotyczących ochrony praw niewielkich akcjonariuszy;

$\checkmark$ dostosowywanie systemu do norm ustanowionych przez Komisję Europejską;

$\checkmark$ wprowadzenie przez niektóre korporacje innowacyjnych rozwiązań dotyczących nadzoru (np. niezależni członkowie zarządu, strony internetowe dla akcjonariuszy).

Największe problemy i wyzwania obecnie stanowią:

$\checkmark$ niewielka aktywność akcjonariuszy;

$\checkmark$ niewielka płynność giełdy utrudniająca możliwość walki z systemami kontrolującymi głosy;

$\checkmark$ nadmierna kontrola polityczna nad zarządzaniem oraz nadzorem korporacji publicznych;

$\checkmark$ niewystarczające zainteresowanie w praktykach nadzoru korporacyjnego wśród korporacji kontrolowanych przez rodziny;

$\checkmark$ nieefektywność systemu prawnego.

\subsection{System nadzoru korporacyjnego w Niemczech oraz porównanie systemów polskiego oraz niemieckiego}

W Niemczech system nadzoru korporacyjnego jest oparty o Niemiecki Akt Prawny dotyczący Spółek Giełdowych (German Stock Corporation Act z 1965 roku). Zawiera on obowiązkowe warunki dotyczące nadzoru korporacyjnego. Oprócz tego, istnieją także dodatkowe, wolontaryjne akty prawne, które dotyczą międzynarodowych oraz narodowych kodów w zakresie nadzoru korporacyjnego. Ostatecznym etapem kształtowania systemu nadzoru korporacyjnego są ustalenia utworzone przez samą korporację. Najczęściej są one zawarte w statucie korporacji i w indywidualnych kontraktach $\mathrm{z}$ akcjonariuszami ${ }^{6}$.

\footnotetext{
${ }^{5}$ Ibidem, 177-191.

${ }^{6}$ Ibidem, 36-58.
} 
Niemiecki system prawny dotyczący korporacji oferuje kilka alternatywnych struktur prawnych, z których mogą wybierać założyciele (lub kompanie założycielskie). Wybór tej struktury ma istotny wpływ na system nadzoru korporacyjnego, ze względu na stopień kontroli, jaki mogą uzyskać organy nadzorcze.

Niemiecki system nadzoru korporacyjnego posiada kilka istotnych elementów struktury. Przede wszystkim, podobnie jak w Polsce, korporacja posiada organ zarządczy oraz nadzorczy. Ścisłe rozróżnienie rady nadzorczej oraz zarządu uniemożliwia pojedynczej osobie pełnienie funkcji w obu tych organach jednocześnie. System prawny warunkuje także sposoby rozwiązywania wewnętrznych problemów. Członkowie zarządu są sobie równi i nie posiadają kontroli nad resztą komisji. Istnieje możliwość powołania kierownika zarządu, który ma za zadanie koordynować wysiłki całej komisji, ale jest on jedynie „pierwszym pomiędzy równymi” i nie może narzucać im swojej woli. W radzie nadzorczej znajdują się także osoby reprezentujące interesy pozostałych grup związanych z korporacją, np. pracowników lub udziałowców mniejszościowych. Ich obecność ma za zadanie uniemożliwić zarządowi nadużycia i wzmacnianie swojej pozycji kosztem mniejszych grup ${ }^{7}$.

System nadzoru korporacyjnego w obu tych krajach zawiera więc bardzo podobne podstawowe struktury. Pomimo różnic w kulturze niemieckiej i polskiej, systemy nadzoru korporacyjnego w obu krajach są prawie identyczne. Normy prawne wymagają rozdzielenia organu zarządzającego i organu nadzorczego, reprezentacji mniejszych grup interesariuszy w radzie nadzorczej oraz niezależności członków zarządu. Kanwa obu systemów jest więc identyczna, a różnice wynikają z indywidualnych preferencji zarządu oraz właścicieli. W obu krajach podstawowym źródłem finansowania jest kapitał obcy, a kapitał akcyjny znajduje się w posiadaniu niewielkich grup akcjonariuszy. Systemy te ograniczają dynamikę przedsiębiorstw oraz opierają się na bezpiecznym kreowaniu długoterminowej wartości.

Na podstawie analizy tych dwóch krajów pod kątem systemu nadzoru korporacyjnego możemy rzeczywiście zauważyć, że różne kraje stosują takie same lub bardzo podobne systemy rachunkowości.

\footnotetext{
${ }^{7}$ Ibidem.
} 


\section{Porównanie systemów nadzoru korporacyjnego na praktycznym przykładzie korporacji działających w Polsce i w Niemczech}

\subsection{Przedstawienie systemu nadzoru korporacyjnego na przykladzie grupy Tauron $^{8}$}

Skonsolidowane sprawozdanie grupy Tauron zawiera cały rozdział opisujący działanie nadzoru korporacyjnego w grupie. W rozdziale opisane są przyjęte przez spółkę zasady z dokumentu Dobre Praktyki Spółek Notowanych na GPW, którymi są objęte spółki giełdowe.

Spółka stosowała zasady obligatoryjne oraz dobrowolne z wyłączeniem zasady z rozdziału IV pkt. 10 Dobrych Praktyk, dotyczącego transmitowania obrad walnego zgromadzenia z możliwością komunikacji z nieobecnymi akcjonariuszami. Opisane są również zasady funkcjonowania zarządu, walnego zgromadzenia i rady nadzorczej.

Zarząd jest organem o składzie od jednej do sześciu osób, powołanych na trzyletnie kadencje przez radę nadzorczą. Zarząd odpowiedzialny jest za prowadzenie spraw spółki oraz jej reprezentację.

Rada nadzorcza jest organem liczącym od pięciu do dziewięciu osób innych niż osoby w zarządzie powoływanych przez walne zgromadzenie na trzyletnie kadencje. W radzie, co najmniej dwie osoby muszą spełniać warunek niezależności od spółki, a swoją niezależność potwierdzają oświadczeniem. Głównymi kompetencjami rady jest sprawowanie ciągłego nadzoru nad działalnością spółki. Wyraża ona opinie na temat działalności, oceniają wnioski zarządu oraz plan roczny na przyszłą działalność. Rada nadzorcza niezbędna jest również do uchwalania regulaminu zarządu, akceptowania sprzedaży i zakupu środków trwałych oraz wyboru biegłego rewidenta do przeprowadzania badania sprawozdania spółki. Rada nadzorcza może powoływać zespoły i komitety do wykonywania określonych czynności, m.in.:

$\checkmark$ Komitet Audytu - odpowiedzialny za monitorowanie sporządzania sprawozdań finansowych oraz monitorowanie czynności rewizji finansowej,

\footnotetext{
${ }^{8}$ Opracowanie własne na podstawie sprawozdania skonsolidowanego Grupy Kapitałowej Tauron za rok 2015.
} 
Komitet Nominacji i Wynagrodzeń - odpowiedzialny za ocenianie kandydatów do zarządu i opracowywanie systemu wynagrodzeń dla członków zarządu,

Komitet Strategii - ocenia plany wieloletnie i strategię korporacyjną, monitoruje realizację zadań strategicznych.

Walne Zgromadzenie składa się z akcjonariuszy i jest odpowiedzialne za powoływanie członków rady nadzorczej, podział zysku, ustalanie wysokości wynagrodzeń członków rady, przekształcanie i podział spółki. Zgodnie z zasadami Dobrych Praktyk spółka zobowiązana jest do posiadania w organach również kobiet, lecz nie ma określenia co do ich ilości.

\subsection{Przedstawienie systemu nadzoru korporacyjnego na przykładzie grupy Bosch $^{9}$}

Grupa kapitałowa Bosch opiera nadzór korporacyjny na zasadach: uczciwości, odpowiedzialności, przejrzystości, otwartości i zaufaniu. Przykładają uwagę do prowadzenia działalności legalnie i zgodnie z zasadami etyki.

Grupa kapitałowa Bosch w swoim sprawozdaniu finansowym opisuje zasady działania nadzoru korporacyjnego, spółka w nim powołuje organy:

1. Zarząd - organ odpowiedzialny za opisywanie strategii działalności oraz zarządzanie firmą, jako całością;

2. Radę nadzorczą - organ posiadający dwudziestu członków, dziesięciu z nich jest akcjonariuszami oraz dziesięciu członków wybranych przez pracowników firmy; rada nadzorcza jest odpowiedzialna za nadzorowanie prac zarządu oraz doradzanie w sprawach prowadzenia działalności, a także zajmuje się monitorowaniem sporządzania sprawozdań finansowych, a następnie wyborem audytorów i nadzorowaniem ich pracy; może ona powoływać komitety do wykonywania zadań między innymi:

$\checkmark$ Komitet Audytu - odpowiedzialny za nadzorowanie sporządzania sprawozdań oraz zatrudnienie i nadzorowanie audytu,

$\checkmark$ Komitet Transferu Akcji,

${ }^{9}$ Opracowanie własne na podstawie sprawozdania skonsolidowanego Grupy Kapitałowej Bosch za rok 2015. 
$\checkmark$ Komitet Nominacji i Wynagrodzeń - odpowiedzialny za wybieranie członków zarządu oraz wyznaczanie im wysokości wynagrodzenia,

$\checkmark$ Komitet CSR - zajmujący się działaniami firmy związanymi ze społeczną odpowiedzialnością biznesu, planowaniem działań, nadzorowaniem ich.

Grupa Bosch bazując na niemieckim prawie zobowiązana jest do powoływania kobiet do rady nadzorczej. Sama spółka ustaliła, że co najmniej $20 \%$ członków rady nadzorczej powinny stanowić kobiety, jednak w składzie zarządu nie przewiduje kobiet aż do 2017 roku. Zobowiązuje się również do podniesienia liczby kobiet zatrudnionych na innych stopniach zarządzania firmą.

\subsection{Porównanie systemów nadzoru korporacyjnego w obu przedsiębiorstwach oraz podsumowanie}

Na przykładzie powyższych firm można łatwo zauważyć, że struktury nadzoru korporacyjnego są bardzo podobne, pomimo tego, że obie korporacje pochodzą z różnych krajów. Obie korporacje wykorzystują dwuczłonową strukturę, czyli podział na zarząd oraz radę nadzorczą.

W obu przypadkach, zarząd jest organem, który zajmuje się podejmowaniem decyzji oraz kierowaniem spółką. Odpowiada on także za reprezentację spółki. Wszyscy członkowie zarządu są sobie równi i nie mogą narzucać innym swojej woli. Dotyczy to także prezesa, który ma za zadanie motywować pozostałych członków zarządu do wspólnego działania.

$\mathrm{Z}$ racji dwuczłonowej struktury badanych korporacji, posiadają one także radę nadzorczą. Zadaniem rady nadzorczej jest kontrolowanie działań przedsiębiorstwa, doradzanie $\mathrm{w}$ sprawach przedsiębiorstwa oraz sprawowanie stałego nadzoru nad zarządem spółki. Pomimo różnic w rozmiarze rady nadzorczej (Turon zakłada, że powinno to być od pięciu do dziewięciu osób, Bosch z kolei wymaga dwudziestu członków) obie firmy zabraniają członkostwa w zarządzie oraz radzie nadzorczej jednocześnie. Rada nadzorcza reprezentuje interesy różnych grup - w przypadku Boscha połowę rady nadzorczej stanowią akcjonariusze, a połowę osoby wybrane przez pracowników. W przypadku Taurona przynajmniej dwie osoby mają być niezależne od spółki. 
Ważną funkcją rady nadzorczej jest prawo do powoływania komitetów. Oba przedsiębiorstwa korzystają z Komitetu Audytu oraz Komitetu Nominacji i Wynagrodzeń. Komitety mają za zadanie zajmować się konkretnymi kwestiami dotyczącymi przedsiębiorstwa. Komitet Audytu odpowiada za kontrolę poprawności sprawozdań finansowych i czynności rewizji finansowej. Zadaniem Komitetu Audytu jest więc zapewnienie akcjonariuszy o rzetelności i jasnym przedstawianiu sytuacji finansowej i majątkowej spółki. Dzięki temu mogą oni łatwo określać, czy przedsiębiorstwo spełnia pożądane przez nich wskaźniki.

Funkcją Komitetu Nominacji i Wynagrodzeń jest ocenianie pracy wykonanej przez członków zarządu oraz tego, jak należy ich wynagrodzić. Zewnętrzna metoda oceniania ma za zadanie uniemożliwić zarządowi przyznawanie sobie premii, pomimo nieefektywnego prowadzenia spółki.

Oba przedsiębiorstwa są także zobowiązane do posiadania pewnej liczby kobiet w zarządzie. Firma Bosch samodzielnie określiła, że przynajmniej $20 \%$ członków rady nadzorczej powinna być płci żeńskiej.

Jak widać z powyższego porównania, pomimo licznych różnic pomiędzy przedsiębiorstwami - inne branże, skala działalności, państwa, w których znajdują się siedziby - ich systemy nadzoru korporacyjnego są do siebie bardzo podobne. Większość różnic wynika z indywidualnego sposobu prowadzenia firmy, ale ich funkcje i założenia pozostają takie same.

\section{Zakończenie}

Mimo różnic kulturowych, branży i różnic w aktach prawych w obu krajach, jesteśmy w stanie zauważyć duże podobieństwo w systemie nadzoru korporacyjnego obu tych firm. Różnice kulturalne coraz bardziej się zacierają, szczególnie, że większość firm obecnie ma swoje siedziby na całym świecie i ujednolica się ich zarządzanie.

Rola nadzoru korporacyjnego mimo już wielkiego znaczenia w zarządzaniu korporacjami, nadal rośnie. Coraz bardziej wymaga się od firm przestrzegania zasad, które bardziej ujednolicą sprawozdawczość oraz nadzór nad ich działalnością. Obecny proces globalizacji zmusza firmy do rywalizowania na skalę całego globu. Różnice miedzy podejściem do nadzoru korporacyjnego między różnymi kulturami zacierane są naturalnie 
przez większą różnorodność kultur w krajach spowodowaną migracjami ludności. Ważną rolę odgrywają również tworzone systemy prawne obejmujące większe grupy państw.

\section{Bibliografia}

Borowiecki R., Kwieciński M., Informacja w zintegrowanej Europie. koncepcje i narzędzia zarządzania wobec wyzwań i zagrożeń, Difin, Warszawa 2006.

Lis K., Nadzór korporacyjny, Oficyna Ekonomiczna, Kraków 2005.

Mallin Ch., Handbook on International Corporate Governance, wyd. 2, Cheltenham, Edward Elgar Publishing, Nowy Jork 2011.

Penc J., Encyklopedia zarzadzania. Podstawowe kategorie i terminy, Wyższa Szkoła Studiów Międzynarodowych, Łódź 2008.

Skonsolidowane sprawozdanie finansowe Grupy Kapitałowej TAURON za 2015 rok.

Skonsolidowane sprawozdanie finansowe Grupy Kapitałowej Bosh za 2015 rok. 